\author{
Jan Woźniak* \\ ORCID: 0000-0003-3362-1105 \\ Uniwersytet Wrocławski
}

DOI: $10.19195 / 1733-5779.27 .2$

\title{
Trendy zmian na rynku muzycznym w Polsce
}

\author{
JEL Classification: M300
}

Słowa kluczowe: rynek muzyczny, branża muzyczna, fonogram, muzyka strumieniowana.

Keywords: music market, music brand, phonogram, music streaming.

Abstrakt: Rynek muzyczny to niezwykle dynamicznie rozwijający się segment ogólnoświatowej gospodarki. Nowoczesne rozwiązania, jak np. streaming muzyki, powodują duże zmiany $\mathrm{w}$ procesie dystrybucji fonogramów na całym świecie. $\mathrm{Z}$ tego powodu coraz więcej słuchaczy wybiera internetowe platformy, które oferują bogatą fonotekę po opłaceniu odpowiedniego abonamentu. Celem niniejszego artykułu jest dokonanie charakterystyki rynku muzycznego oraz zaprezentowanie działań marketingowych stosowanych przez przedsiębiorstwa z branży muzycznej, a także przedstawienie wyników badań ankietowych dotyczących wpływu działalności marketingowej na zachowania nabywców na rynku muzycznym w Polsce.

Praca powstała na podstawie badań wtórnych oraz pierwotnych, dotyczących zachowań nabywców oraz analizy strukturalnej rynku muzycznego.

\section{Trends of changes on the music market in Poland}

Abstract: The music market is a very dynamically growing segment of the worldwide economy. Modern solutions, for example music streaming, cause significant changes in the phonogram distribution process on a world scale. For this reason more and more listeners choose internet platforms, which offer a rich library of records for a subscription fee. The objective of this article is to provide a detailed description of the music market, to present marketing operations carried out by businesses from the music sector and to present results of survey studies on the impact of marketing operations on buyer's behavior on the music market in Poland. This work is based on primary and secondary research concerned with buyers' behaviors and a structural analysis of the music market.

* Opiekun naukowy (Scientific Tutor) — prof. dr hab. Katarzyna Szalonka 


\section{Wprowadzenie}

Rynek muzyczny to bardzo szeroka gałąź ogólnoświatowego rynku, która charakteryzuje się nieprzeciętnie dynamicznym rozwojem technologicznym i wysokim poziomem innowacyjności. Rynek ten możemy podzielić na trzy branże: fonograficzną, koncertową oraz publishingową. Wiek XXI cechuje bardzo wysoki wzrost popularności nowoczesnych rozwiązań dystrybucji muzyki, tak zwanych streamingów, które powoli wypierają klasyczne wydania na nośnikach dźwięku. Należy również pamiętać o produktach związanych bezpośrednio z techniczną obsługą nośników czy „streamingów”, czyli dobrach związanych z rynkiem elektroniki użytkowej, takich jak chociażby słuchawki czy inny sprzęt muzyczny pozwalający na odtwarzanie dźwięku. Z powodu szerokiego kontekstu pojęcia branży muzycznej przedsiębiorstwa i korporacje specjalizujące się w tej dziedzinie muszą szukać rozwiązań, które wychodzą poza pojęcie tradycyjnych praktyk marketingowych. Nowoczesna komunikacja marketingowa wykorzystująca szybki rozwój technologii i płynnie zmieniająca relacje konsument-przedsiębiorca/ artysta $\mathrm{z}$ pionowych na poziome stanowi w dzisiejszych czasach główne źródło skutecznej reklamy szerokiej gamy produktów z branży muzycznej.

Celem niniejszego artykułu jest charakterystyka rynku muzycznego, zaprezentowanie działań marketingowych stosowanych przez przedsiębiorstwa z branży muzycznej, a także przedstawienie wyników badań ankietowych dotyczących wpływu działalności marketingowej na zachowania nabywców w Polsce.

Autor przeprowadził badania pierwotne, stosując technikę kwestionariusza online. Badania zostały przeprowadzone na terenie Polski w terminie od 20 kwietnia do 20 maja 2018 roku, udział w nich wzięło 405 osób. Próba została dobrana na podstawie kryteriów demograficznych — płci, wieku oraz dochodów na osobę w gospodarstwie domowym. W artykule zaprezentowane zostały również wyniki badań wtórnych, między innymi IFPI, które dotyczą wyborów konsumentów na rynku muzycznym. Z przeprowadzonych przez autora badań wynika, iż zdecydowana większość Polaków - ponad 62\% ankietowanych — kupuje nośniki dźwięku za pośrednictwem internetowych sklepów muzycznych. Najchętniej wybieranym przez konsumentów w Polsce nośnikiem są płyty CD, na które decyduje się aż $78,4 \%$ badanych. Dla porównania zdigitalizowane, to znaczy cyfrowe wersje albumów czy pojedynczych utworów, które są możliwe do pobrania zaraz po zakupie i zapisania na dysku komputera lub innego urządzenia z dostępem do Internetu, wybiera jedynie 35\% konsumentów. Jeśli chodzi o reklamowanie produktów z branży muzycznej, to znaczny wpływ reklamy na wybór danego produktu deklaruje 37,5\% ankietowanych kobiet i jedynie $8 \%$ mężczyzn.

\section{Charakterystyka produktu na rynku muzycznym}

Produktem w ujęciu branży fonograficznej możemy nazwać każdy nośnik zawierający zapis ścieżki dźwiękowej: płyta kompaktowa, winylowa, kaseta — czyli 
tak zwane fonogramy ${ }^{1}$. Oprócz tradycyjnych nośników możemy wyróżnić także nowoczesne formy produktu branży fonograficznej — wydania cyfrowe, a także muzykę strumieniowaną. Muzyka strumieniowana to utwory, które wypożyczamy z internetowego zbioru (na przykład Spotify, Tidal, iTunes) w czasie rzeczywistym, nie wykupując ich na własność. Biorąc pod uwagę tendencję wzrostową zainteresowania strumieniowaniem muzyki ${ }^{2}$, możemy również włączyć ją do grona produktów branży fonograficznej ${ }^{3}$. Poza wymienionymi już fonogramami pozostaje jeszcze zdigitalizowana/cyfrowa muzyka, która jest dostępna do pobrania bezpośrednio na dysk na przykład komputera ${ }^{4}$. Spełnia ona wszelkie ogólne cechy produktu zaproponowane przez P. Kotlera ${ }^{5}$, dlatego umieszczenie jej na liście obok muzyki strumieniowanej fonogramów jest obowiązkowe. Liczby zdają się potwierdzać ogólny trend na muzykę strumieniowaną i cyfrową, co w ogólnym rozrachunku prowadzi do zmiany w strukturze dystrybucji muzyki. Przenosi się ona do wersji zdigitalizowanej i strumieniowanej, zastępując tradycyjne nośniki dźwięku' ${ }^{6}$.

Według Patryka Gałuszki istnieje również druga forma „produktu” na rynku fonograficznym, którą jest kariera samego artysty wykonującego utwory dla danej wytwórni muzycznej ${ }^{7}$. Producent liczy na to, że inwestując środki w karierę wykonawcy, którego ma pod swoją „opieką, będzie mógł osiągnąć miarodajne zyski w dłuższym okresie. W ten sposób fonogramy stają się oddzielnym produktem, który istnieje jedynie w formie pomocy w dotarciu do twórczości muzyka ${ }^{8}$.

\section{Rynek fonograficzny — struktura podaży}

Aby właściwie dokonać analizy rynku fonograficznego, należy na początku ustalić jego definicję — jest to część ogólnego rynku rozrywki oraz dóbr kultury, której uczestnikami są producenci i odbiorcy nagrań ${ }^{9}$. Producenci to najczęściej wytwórnie muzyczne, których zadaniem jest wyszukiwanie artystów oraz materiałów dla nich, przeznaczanie środków na nagranie materiału muzycznego,

1 P. Gałuszka, Biznes muzyczny - ekonomiczne i marketingowe aspekty fonografii, Warszawa 2009, s. 96.

2 Raport IFPI, Global Music Raport - Annual State of Industry, 2018, s. 7. https://www.ifpi. org/downloads/GMR2018.pdf (dostęp: 20.11.2018).

3 P. Gałuszka, op. cit., s. 96.

${ }^{4}$ Legalna Kultura, Jak dystrybucja cyfrowa zmienia muzyke - debata w Opolu, https://www. legalnakultura.pl/pl/legalna-kultura/dzialamy/blog/1175,jak-dystrybucja-cyfrowa-zmienia-muzyke-debata-w-opolu (dostęp: 20.11.2018).

5 P. Kotler, G. Armstrong, J. Saunders, V. Wong, Marketing: podręcznik europejski, Warszawa 2002, s. 615.

6 P. Gałuszka, H. Kartajaya, I. Setiawan, Marketing 4.0, Warszawa 2017, s. 33.

7 P. Gałuszka, Biznes muzyczny.., s. 96.

8 Ibidem, s. 96-97.

9 P. Gałuszka, K. Korzeniewska, K.M. Wyrzykowska, A. Jagiełło-Skupińska, Rynek fonograficzny w Polsce 2011/2012, Warszawa 2013, s. 7. 
czyli produkcję, a także przeznaczanie środków na dystrybucję oraz promocję wyprodukowanych fonogramów ${ }^{10}$.

$\mathrm{Na}$ świecie występuje kilka wytwórni muzycznych, których udział w globalnym rynku nagrań stanowi znaczą większośćc ${ }^{11}$ — nazywane są majors i zalicza się do nich: Universal Music Group, Sony Music Entertainment oraz Warner Music Group. Należy podkreślić, że wymienione koncerny w 2017 roku posiadały ponad $70 \%$ udziałów w opisywanym rynku, jednak równocześnie trzeba zaznaczyć, że niezależne wytwórnie muzyczne znacznie zyskały na popularności i ich udział w rynku w tym roku wyniósł nieco mniej niż $30 \%{ }^{12}$, co w ogólnym rozrachunku oznacza wzrost o prawie $20 \% \mathrm{w}$ porównaniu do roku $2012^{13}$.

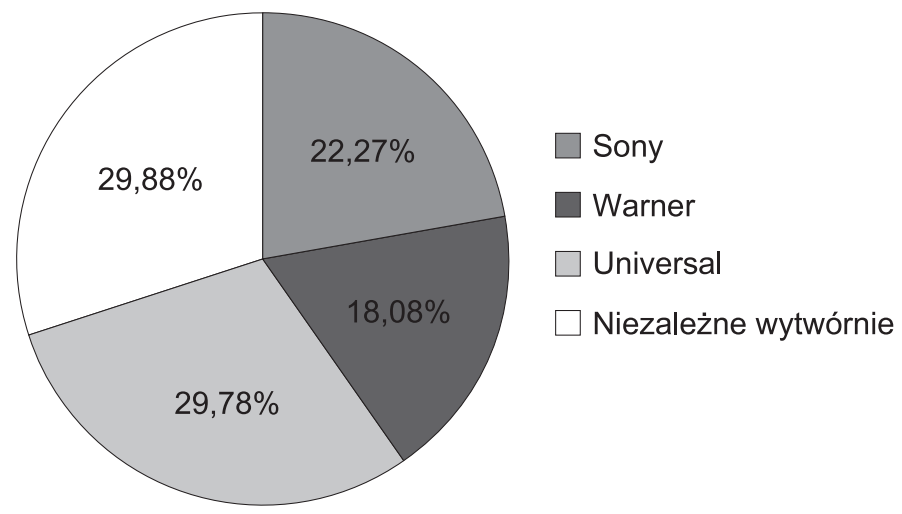

Wykres 1 . Udziały w rynku poszczególnych wytwórni w 2017 roku

Źródło: opracowanie własne na podstawie raportu IFPI.

Nie należy zapominać o zmianach, jakie zachodzą w strukturze podaży na rynku fonograficznym, stymulowanych poprzez rozwój technologii. Przede wszystkim muzyka stała się powszechnie dostępna za pośrednictwem Internetu, co pozwoliło na jej dystrybuowanie w nowoczesny sposób - jako pliki z muzyką, które można pobrać bezpośrednio na dysk praktycznie każdego urządzenia z dostępem do sieci i oczywiście wspominana już muzyka strumieniowana.

10 Pop Run The World, Jak dzieli się rynek muzyczny?, 2014, https://popruntheworld.wordpress.com/2014/10/07/jak-dzieli-sie-rynek-muzyczny/ (dostęp: 21.11.2018).

11 P. Gałuszka, Największe koncerny muzyczne - majors, 2007, http://pga.blox.pl/2007/06/ Najwieksze-koncerny-muzyczne-majors.html (dostęp: 21.11.2018).

12 T. Ingham, Independents ruled global market share in 2017 - but Universal was king of streaming, https://www.musicbusinessworldwide.com/independents-ruled-global-market-sharein-2017-but-universal-was-king-of-streaming/ (dostęp: 21.11.2018).

13 Business Wire, The Nielsen Company \& Billboard's 2012 Music Industry Report, 2013, https:// www.businesswire.com/news/home/20130104005149/en/Nielsen-Company-Billboard\%E2\%80\% 99s-2012-Music-Industry-Report\#.VF6Ts5_YiDw (dostęp: 21.11.2018). 
Markami, które oferują muzykę gotową do bezpośredniego pobrania na pamięć komputera, są chociażby: iTunes Store, Amazon, Napster, 7digital, eMusic ${ }^{14}$, Empik czy Bandcamp. Ostatnia z wymienionych witryn przeznaczona jest do sprzedaży muzyki przez niezależnych artystów — dzięki Bandcampowi otrzymali oni w ciągu dziesięciu lat istnienia tej platformy łącznie aż 345 milionów dolarów od swoich fanów na całym świecie ${ }^{15}$.

Do najpopularniejszych serwisów zajmujących się strumieniowaniem muzyki należy zaliczyć Spotify, Apple Music, Amazon, Tencent Music, Deezer oraz Google Music ${ }^{16}$. Pierwsze dwie platformy w swoich bibliotekach zawierają imponujące liczby — od 30 do 40 milionów — utworów, które można w każdej chwili wyszukać i odtworzyć na przeznaczonych do tego urządzeniach.

[\%]

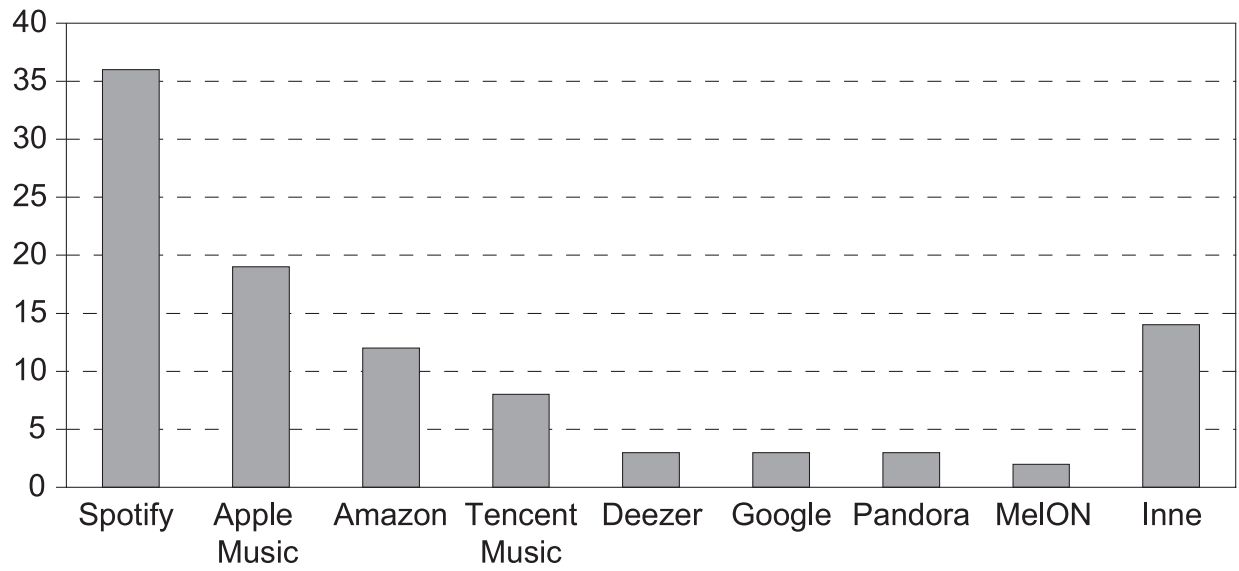

Wykres 2. Udział w ogólnoświatowym rynku poszczególnych platform strumieniujących muzykę w 2018 roku

Źródło: opracowanie własne na podstawie MIDiA Research Music Subscriber Market Share Model 09/18.

Większość z wymienionych systemów strumieniowania muzyki posiada swoje własne aplikacje, które są przeznaczone do używania na komputerach, smartfonach, konsolach do gier, telewizorach, a nawet smartwatchach czy wybranych samochodach ${ }^{17}$. Dlatego odtwarzanie utworów udostępnianych w formie biblio-

14 M. Harris, 6 Best Online Music Sites for Downloading Songs, 2019, https://www.lifewire. com/best-online-music-sites-for-downloading-songs-2438415 (dostęp: 20.02.2018).

15 Dane dostępne są w zakładce „o nas” na stronie internetowej https://bandcamp.com/about (dostęp: 3.12.2018).

16 Raport IDiA, Research Music Subscriber Market Share Model 09/18, https://musicindustryblog.wordpress.com/2018/09/13/mid-year-2018-streaming-market-shares/ (dostęp: 3.12.2018).

17 Dane dostępne są w zakładce „o nas” na stronie internetowej https://support.spotify.com/us/ (dostęp: 3.12.2018). 
teki nie spotyka się z żadnymi ograniczeniami, a wręcz przeciwnie - pozwala na większą mobilność, której często brakuje w tradycyjnych nośnikach dźwięku.

Wielkie koncerny muzyczne nie prowadzą swoich platform streamingowych czy sklepów z muzyką online, dlatego zawierają one umowy międzynarodowe z cyfrowymi detalistami ${ }^{18}$, czyli na przykład Spotify, Apple Music, 7digital itd. Jednak mimo niewątpliwych zysków osiąganych dzięki udostępnianiu utworów do fonotek platform strumieniujących muzykę wytwórnie z grupy majors na samym początku bardzo niechętnie odnosiły się do zmian w podaży na rynku fonograficznym przez Internet. P. Gałuszka wskazuje nawet, iż koncerny te przez pewien czas charakteryzowała „krótkowzroczność marketingowa”, która w dużym skrócie objawia się brakiem szerokiego spojrzenia na rynek, a także ignorowaniem nowych warunków na nim zachodzących ${ }^{19}$. Wielkie koncerny faktycznie nie dostosowały odpowiednio swojej polityki marketingowej — w dalszym ciągu stawiają w głównej mierze na tłoczenie fizycznych nośników, mimo że wciąż odnotowywane są globalne wzrosty konsumpcji muzyki zdigitalizowanej/strumieniowanej ${ }^{20}$.

\section{Charakterystyka popytu oraz preferencje zakupowe konsumentów na rynku fonograficznym}

Odbiorca produktu na rynku muzycznym jest definiowany przez styl muzyczny, który preferuje, choć i to nie jest regułą. Niewątpliwie popyt będą reprezentować osoby, które posiadają elektronikę użytkową odpowiednią do odtworzenia zapisu dźwiękowego i oczywiście kupują fonogramy z legalnych źródeł.

Na podstawie badania - internetowego kwestionariusza - przeprowadzonego na próbie 405 osób możemy poznać reprezentatywnego konsumenta tego rynku. Prawie połowa ankietowanych dokonujących zakupów nośników dźwięków to osoby w wieku od 18 do 25 lat. Dodatkowo na ponad 35\% osób, które wzięły udział w badaniu, przypada miesięczny dochód w granicach od 2000 do $3500 \mathrm{zł}$. Warto zaakcentować, iż średnia łączna kwota wydatków rocznych wszystkich osób ankietowanych to nieco ponad 40 tysięcy złotych. Bazując na zebranych danych, można jednoznacznie stwierdzić, że wydatki te są mocno zróżnicowane (patrz wykres 3).

Można zaobserwować, iż odpowiedzi na pytanie o średnie roczne wydatki na nośniki dźwięku są dość różnorodne. Największy odsetek osób to konsumenci wydający rocznie około 100-250 zł na fonogramy, a zaraz po nich, z wynikiem 19\%, plasują się osoby wydające średnio nieco ponad $375 \mathrm{zł} \mathrm{na} \mathrm{takie} \mathrm{produkty.} \mathrm{Warto}$ odnotować również, iż duża grupa ankietowanych, bo aż 30\% osób, na nośniki

18 P. Gałuszka, K. Korzeniewska, K.M. Wyrzykowska, A. Jagiełło-Skupińska, op. cit., s. 118.

19 P. Gałuszka, Biznes muzyczny..., s. 210-211.

20 M. Gajewski, Amerykanie już nie chca muzyki na własność. Wystarcza im ta strumieniowana, 2018, https://www.spidersweb.pl/rozrywka/2018/07/12/muzyka-strumieniowanie-kontra-kupowanie/ (dostęp: 14.12.2018). 


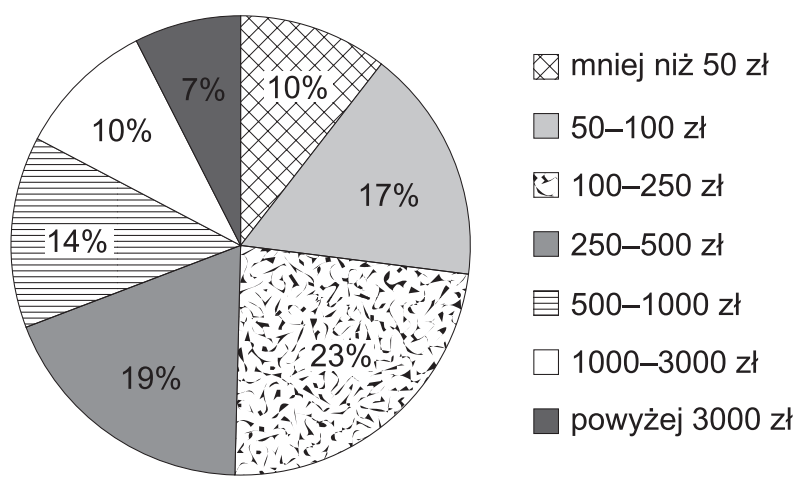

Wykres 3. Średnie roczne wydatki na nośniki dźwięku wśród osób ankietowanych Źródło: opracowane na podstawie przeprowadzonych badań.

z zapisem muzycznym wydaje ponad $500 \mathrm{zł} \mathrm{rocznie.} \mathrm{Gdy} \mathrm{weźmiemy} \mathrm{pod} \mathrm{uwagę}$ dwie największe grupy wydatków, to jest $100-250 \mathrm{zł}$ oraz $350-500 \mathrm{zl}$, to mediana równa jest 375 zł. Gdy porównamy tę liczbę ze średnimi rocznymi wydatkami na produkty rynku muzycznego w USA, które według Nielsen Music 3602017 U.S. Report w 2017 roku wynosiły około 156 dolarów ${ }^{21}$, możemy bez wątpienia stwierdzić, iż udział Polaków nie odstaje znacząco od globalnych liczb.

Znaczna większość ankietowanych kupuje w ciągu roku od 1 do 15 sztuk nośników dźwięku — taki przedział wybrało w sumie aż 58,5\% osób. Jedynie 24,7\% respondentów decyduje się w ciągu roku na zakup od 15 do 50 sztuk nośników dźwięku.

W dalszej części formularza ankietowego zadawano pytanie dotyczące preferencji zakupowych samych nośników.

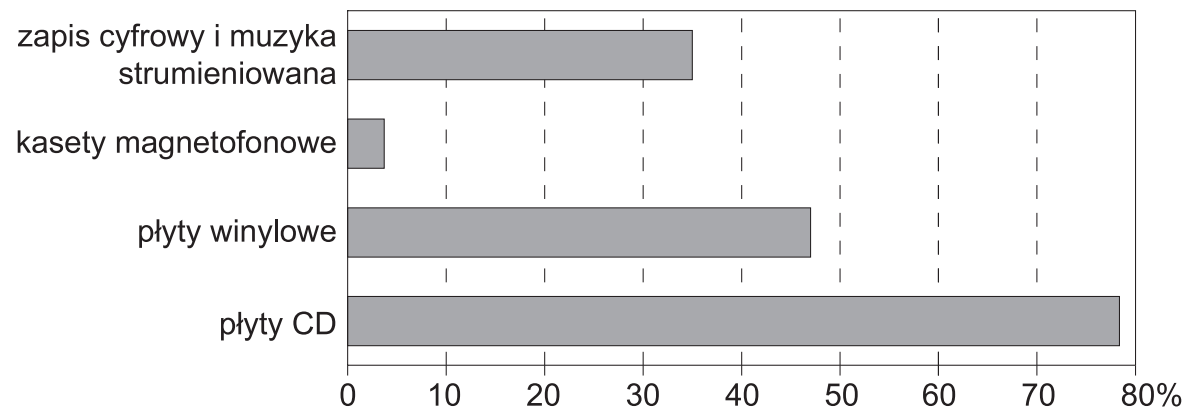

Wykres 4. Najczęściej wybierane fonogramy przez ankietowanych

Źródło: opracowane na podstawie przeprowadzonych badań.

21 E. Christman, Nielsen 360 Study Finds Consumers Love Streaming Music, But Radio Still Strong, 2017, https://www.billboard.com/articles/business/8031468/nielsen-music-360-2017-reportstreaming (dostęp: 15.12.2018). 
Najchętniej kupowanym nośnikiem dźwięku są płyty CD, zaraz po nich plasują się płyty winylowe. Zapis cyfrowy oraz subskrypcje muzyki strumieniowanej są dopiero na trzecim miejscu, co może świadczyć o tym, iż popularne w krajach wysokorozwiniętych streamingi muzyczne dopiero zaczynają pojawiać się w świadomości konsumentów w Polsce. Porównując te wyniki do danych uzyskanych z Global Music Report 2018, możemy stwierdzić, iż większość światowych zysków ze sprzedaży fonogramów pochodzi właśnie ze streamingów muzyki aż $38 \%$ w całości rynku ${ }^{22}$.

Przy okazji warto wspomnieć o najpopularniejszych portalach oferujących strumieniowanie muzyki w USA. Na podstawie danych statystycznych uzyskanych z witryny www.statista.com możemy stwierdzić, iż w marcu 2018 roku zdecydowanie najpopularniejszym serwisem tego typu był Apple Music, który zrzeszał aż 49,5 milionów abonentów. Na drugim miejscu plasowało się Spotify kolejny streamingowy gigant, który skupiał niewiele mniej subskrybentów, bo aż 47,7 milionów. Na kolejnych miejscach uplasowały się: Pandora Radio, Soundcloud, a także Google Play Music ${ }^{23}$.

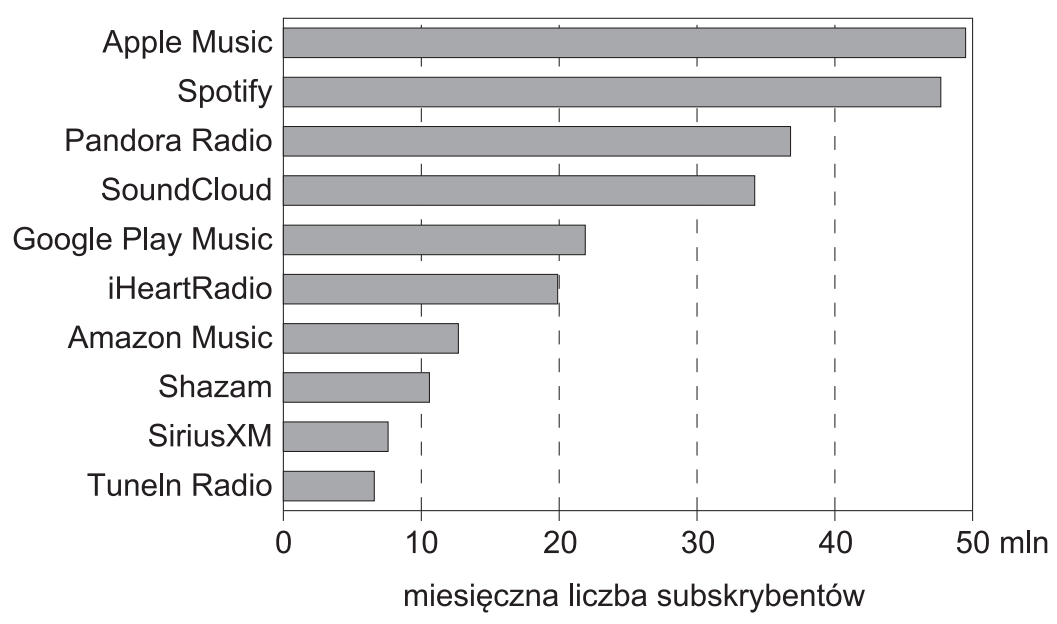

Wykres 5. Najpopularniejsze portale strumieniujące muzykę w marcu 2018 roku

Źródło: opracowano na podstawie https://www.statista.com/statistics/798125/most-popular-us-music-streaming-services-ranked-by-audience/ (dostęp: 15.12.2018).

Badania wykazały, iż Polacy najchętniej kupują fizyczne fonogramy w internetowych sklepach muzycznych oferujących sprzedaż takich nośników, jak płyty

22 Raport IFPI, Global Music Raport - Annual State of Industry, 2018, s. 11, https://www.ifpi. org/downloads/GMR2018.pdf (dostęp: 20.11.2018).

23 Statista, Most popular music streaming services in the United States as of March 2018, by monthly users (in millions), 2018, https://www.statista.com/statistics/798125/most-popular-us-musicstreaming-services-ranked-by-audience/ (dostęp: 15.12.2018). 
CD, kasety magnetofonowe oraz płyty winylowe - aż $62,2 \%$ badanych osób wybrało tę opcję. Kolejnymi najchętniej wybieranymi miejscami zakupu tego typu produktów były księgarnie (w tym na przykład Empik) - 42,1\% oraz internetowe portale aukcyjne, które wybrało 41,4\% osób. Z dosyć słabym, jak mogłoby się wydawać, wynikiem 31,6\% wyborów zakończyły ankietę stacjonarne sklepy z muzyką. Na dalszych pozycjach uplasowały się supermarkety, a także sklepy typu RTV AGD. Oprócz dostępnych do wyboru opcji osoby biorące udział w badaniu zaznaczały, że kupują fonogramy bezpośrednio od samych muzyków (taka opcja dostępna jest chociażby za pośrednictwem strony www.bandcamp.com), jednak osoby te stanowią niewielki odsetek w porównaniu do ogólnej liczby ankietowanych osób.

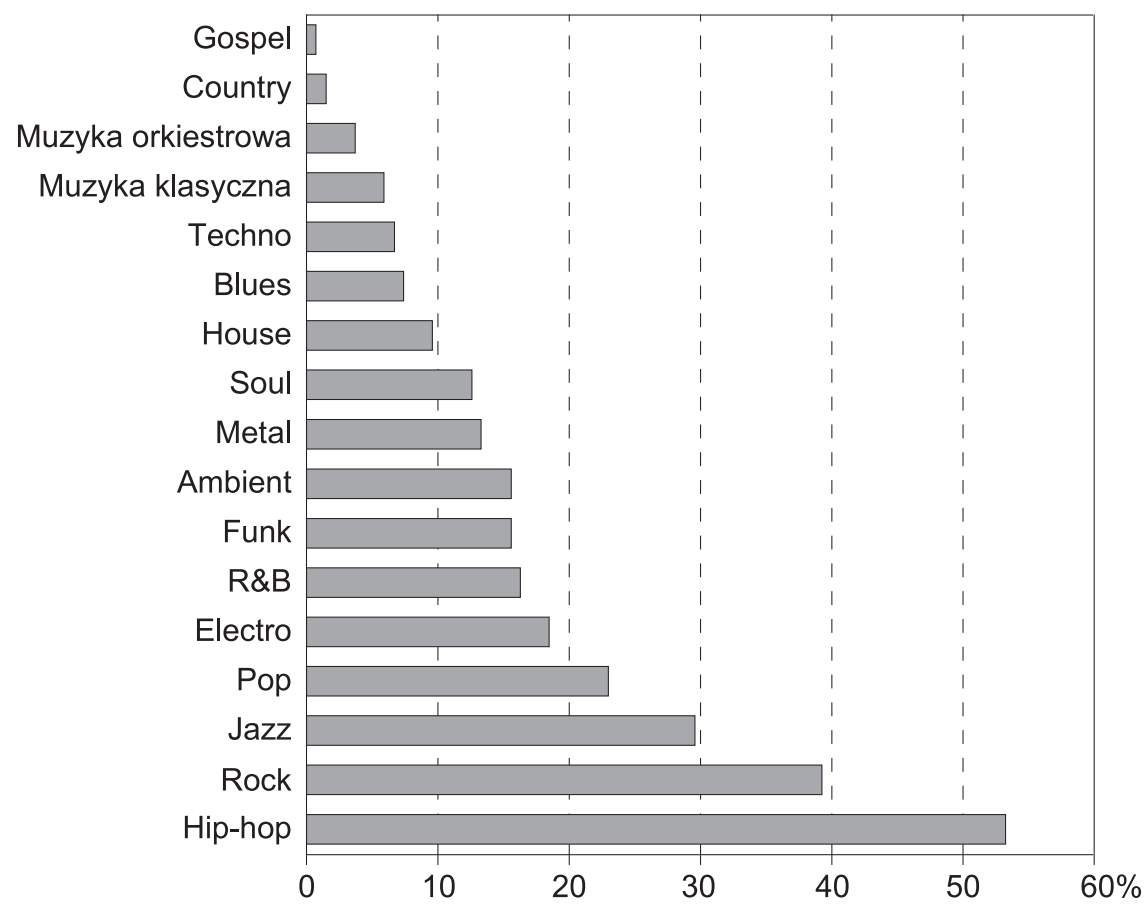

Wykres 6. Preferowane gatunki muzyczne wśród ankietowanych osób

Źródło: opracowane na podstawie przeprowadzonych badan.

Najchętniej wybieranym gatunkiem muzycznym wśród badanych był hip-hop z 50\% wynikiem. Na kolejnych pozycjach uplasowały się rock, jazz, pop oraz electro. Takie rezultaty mogą być podyktowane wiekiem ankietowanych osób, który w znacznej większości wynosił od 18 do 25 lat $^{24}$.

24 Według badania przeprowadzonego przez B. Gaille’a aż 66\% słuchających muzyki hip-hop to osoby w wieku od 18 do 35 lat. B. Gaille, 25 Good Hip Hop Demographics, https://brandongaille. com/25-good-hip-hop-demographics/ (dostęp: 15.12.2018). 
Osoby kupujące nośniki dźwięku najczęściej kupują je na użytek własny, dużo rzadziej te urządzenia wybiera się w formie prezentu (dla bliskich i znajomych). Najważniejszy wyznacznik wyboru danego nośnika dźwięku stanowią dla kupujących parametry nagrania - ankietowani wolą zakupić fonogram droższy, lecz nagrany w dobrej jakości audio. Dopiero drugim wyznacznikiem przy wyborze fonogramów była cena. Równie ważnym kryterium wyboru takiego typu produktów są dla ankietowanych opinie osób, które już wcześniej zakupiły dany fonogram - ponad 53\% badanych korzysta z recenzji publikowanych w Internecie. Dopiero na następnym miejscu jest wygląd, czyli sam design danego wydania. Większość osób ankietowanych zadeklarowała, że nie ma dla nich znaczenia kraj pochodzenia fonogramu. Zdecydowana większość osób wskazała jednak, iż ważna jest dla nich sama wytwórnia, z której pochodzą dane fonogramy - 39,2\% osób zadeklarowało, że ma to dla nich znaczenie.

\section{Strukturalna analiza cenowa fonogramów w Polsce}

Na potrzeby tego artykułu zebrano ceny nośników dźwięku w formie fizycznej, abonentów popularnych serwisów streamingowych oraz muzyki dostępnej do zakupienia i pobrania za pośrednictwem Internetu. Przedstawione dane dotyczą reprezentatywnych artystów różnych gatunków muzycznych, wybranych losowo przez autora artykułu.

Tabela 1. Analiza cen płyt CD w wybranych sklepach w Polsce

\begin{tabular}{|l|c|c|c|c|c|}
\hline \multicolumn{1}{|c|}{$\begin{array}{c}\text { Artysta — album / } \\
\text { Cena w sklepie (w zł) }\end{array}$} & Empik & MediaMark & Gigant.pl & Merlin.pl & MusicCorner.pl \\
\hline $\begin{array}{l}\text { Dawid Podsiadło - } \\
\text { „Małomiasteczkowy” }\end{array}$ & 36,99 & 29,99 & 32,99 & 35,99 & 37,54 \\
\hline $\begin{array}{l}\text { Lil Peep —,Come Over } \\
\text { When You're Sober,Pt.2” }\end{array}$ & 44,99 & 39,99 & 36,99 & 40,99 & 42,20 \\
\hline $\begin{array}{l}\text { Zbigniew Wodecki - } \\
\text { „Zbigniew Wodecki } \\
\text { Debiut” }\end{array}$ & 33,99 & 29,99 & 27,99 & 28,89 & 29,57 \\
\hline Ed Sheeran — „Divide” & 41,99 & 44,99 & 37,99 & 64,99 & 63,37 \\
\hline $\begin{array}{l}\text { Agnieszka Chylińska - } \\
\text { „Pink Punk” }\end{array}$ & 36,99 & 29,99 & 34,99 & 30,99 & 32,29 \\
\hline Matt Dusk - „JetSetJazz” & 40,99 & 39,99 & 43,99 & 39,99 & 37,50 \\
\hline $\begin{array}{l}\text { Pezet, Sidney Polak - } \\
\text { „Radio Pezet” }\end{array}$ & 26,99 & 26,99 & 23,99 & 26,99 & 25,35 \\
\hline
\end{tabular}




\begin{tabular}{|c|c|c|c|c|c|}
\hline $\begin{array}{l}\text { Mark Knopfler — „Down } \\
\text { The Road } \\
\text { Whenever (PL)” }\end{array}$ & 39,99 & 39,99 & 43,99 & 39,99 & 37,50 \\
\hline $\begin{array}{l}\text { Alan Walker - „Different } \\
\text { World” }\end{array}$ & 44,99 & 39,99 & 36,99 & 41,99 & 42,20 \\
\hline $\begin{array}{l}\text { Nirvana — „Nevermind } \\
\text { (Remastered)” }\end{array}$ & 26,99 & 36,991 & 38,99 & 33,90 & 38,70 \\
\hline $\begin{array}{l}\text { Linkin Park — „Living } \\
\text { Things" }\end{array}$ & 30,99 & 26,99 & 58,991 & 55,991 & 29,571 \\
\hline LP — „Heart To Mouth” & 40,99 & 39,99 & 43,991 & 39,99 & 37,59 \\
\hline $\begin{array}{l}\text { Metallica — „Kill'em All } \\
\text { (Remastered)” }\end{array}$ & 53,99 & 34,99 & 35,99 & 33,99 & 33,25 \\
\hline $\begin{array}{l}\text { Imagine Dragons - } \\
\text { „Origins" }\end{array}$ & 54,99 & 39,99 & 56,99 & 51,99 & 49,20 \\
\hline $\begin{array}{l}\text { Jean Michel Jarre - } \\
\text { „Oxygen” }\end{array}$ & 29,99 & 36,99 & 31,99 & 34,991 & 36,37 \\
\hline Suma cen & 585,85 & 537,85 & 586,85 & 601,66 & 572,20 \\
\hline Średnia cena płyty & 39,06 & 35,86 & 39,12 & 40,11 & 38,15 \\
\hline
\end{tabular}

Źródło: opracowanie własne na podstawie danych dostępnych na stronach: Empik.pl, MediaMarkt.pl, Merlin. pl, Gigant.pl, MusicCorner.pl (dostęp: 21.01.2019).

W tabeli nr 1 widoczne są ceny wybranych piętnastu albumów muzycznych $\mathrm{w}$ formie płyty $\mathrm{CD}$ z podziałem na sklepy zarówno stacjonarne, jak i internetowe. Podane ceny zostały pobrane dnia 21 stycznia 2019 roku i są pierwotnymi cenami produktów.

Jak widać, ceny płyt CD są bardzo zróżnicowane, jeśli spojrzymy na nie przez pryzmat wszystkich wybranych pięciu sklepów. W ogólnym rozrachunku najmniej za takie przykładowe zakupy zapłacilibyśmy, wybierając MediaMarkt, w którym wydalibyśmy średnio około 35,86 zł za pojedynczą płytę. W pozostałych sklepach wydalibyśmy średnio nieco więcej niż 4 zł za tego typu produkt. Podsumowując, należy przyjąć, że za płytę CD w sklepie stacjonarnym czy internetowym zapłacimy średnio około 38,46 zł.

Analogicznie postępując, autor wybrał kilka reprezentatywnych pozycji wśród płyt winylowych i dokonał analizy cenowej w trzech różnych sklepach, które oferują ,czarne” płyty. 
Tabela 2. Analiza cen płyt winylowych w wybranych sklepach w Polsce

\begin{tabular}{|c|c|c|c|}
\hline Wykonawca - album / Cena w sklepie (w zł) & Empik & Winylownia.pl & MusicCorner.pl \\
\hline Taco Hemigway — „Trójkąt Warszawski LP” & 57,99 & 74,99 & 59,85 \\
\hline $\begin{array}{l}\text { Lil Peep - „Come Over When You're Sober. } \\
\text { Vol } 1 \& 2 \text { " }\end{array}$ & 143,99 & 149,99 & 142,59 \\
\hline Kult — „Posłuchaj To Do Ciebie” & 111,99 & 129,99 & 124,16 \\
\hline Budka Suflera — „1974-1984” & 79,99 & 87,99 & 77,44 \\
\hline $\begin{array}{l}\text { Zbigniew Wodecki - „Zbigniew Wodecki } \\
\text { Debiut” }\end{array}$ & 52,99 & 79,75 & 77,44 \\
\hline Agnieszka Chylińska — „Forever Child” & 62,99 & 79,75 & 77,44 \\
\hline Elvis Presley — „Elvis Presley” & 108,99 & 89,99 & 89,79 \\
\hline Cure — „Pornography” & 46,99 & 80,00 & 66,49 \\
\hline Michael Buble — „Christmas” & 75,99 & 74,99 & 70,41 \\
\hline Metallica — „Kill'Em All” & 95,99 & 104,00 & 86,44 \\
\hline Suma cen & 837,90 & 951,44 & 872,05 \\
\hline Średnia cena płyty winylowej & 83,79 & 95,14 & 87,21 \\
\hline
\end{tabular}

Źródło: opracowanie własne na podstawie danych dostępnych na stronach: Empik.pl, MusicCorner.pl., Winylownia.pl (dostęp: 21.01.2019).

Ceny płyt winylowych są jeszcze bardziej zróżnicowane niż ceny płyt CD; bardzo duże wahania pomiędzy nimi mogą wynikać bezpośrednio na przykład z umów zawartych między wytwórniami muzycznymi czy też dostawcami a sklepami stacjonarnymi ${ }^{25}$. Warto również zaznaczyć, iż popyt na ten nośnik dźwięku w ostatnich latach zalicza tendencję wzrostową i wcale nie zanosi się na to, by miał to być tylko chwilowy trend ${ }^{26}$.

Najmniej na zakupy nowych płyt winylowych wydamy, wybierając sklep Empik, w którym średnia cena tego produktu wynosi około 83,79 zł. Robiąc zakupy w pozostałych dwóch sklepach, musimy liczyć się z tym, że zapłacimy czasami dużo więcej za interesującą nas pozycję.

Na podstawie danych dostępnych w sklepie internetowym Empik.pl zebranych zostało piętnaście wybranych zapisów cyfrowych albumów muzycznych, a także porównano je do albumów zapisanych na płytach CD.

25 P. Gałuszka, Biznes muzyczny..., s. 117.

26 B. Rosenblatt, Vinyl Is Bigger Than We Thought. Much Bigger, 2018, https://www.forbes. com/sites/billrosenblatt/2018/09/18/vinyl-is-bigger-than-we-thought-much-bigger/\#55cfa75alc9c (dostęp: 16.12.2018). 
Tabela 3. Cena zapisu cyfrowego albumów w porównaniu do wydania na płytach CD w sklepie internetowym Empik.pl

\begin{tabular}{|l|c|c|}
\hline \multicolumn{1}{|c|}{ Wykonawca — nazwa albumu } & $\begin{array}{c}\text { Cena zapisu } \\
\text { cyfrowego (w zł) }\end{array}$ & Cena płyty CD (w zł) \\
\hline Paweł Domagała — „1984” & 28,99 & 36,99 \\
\hline Queen — „The Platinium Collection” & 60,99 & 64,99 \\
\hline $\begin{array}{l}\text { Bradley Cooper, Lady Gada - } \\
\text { “A star is born ST” }\end{array}$ & 53,99 & 54,99 \\
\hline Paluch — „Czerwony Dywan” & 24,99 & 39,99 \\
\hline Dawid Podsiadło — „Małomiasteczkowy” & 45,99 & 36,99 \\
\hline Uniatowski — „Metamorphosis” & 28,99 & 35,99 \\
\hline Kortez — „Mini Dom” & 28,99 & 29,99 \\
\hline Szpaku — „Atypowy” & 24,99 & 35,99 \\
\hline LP — „Heart To Mouth” & 28,99 & 40,99 \\
\hline Quebonafide - „Ezoteryka” & 28,99 & 30,99 \\
\hline Agnieszka Chylińska — „Pink Punk” & 30,99 & 36,99 \\
\hline Imagine Dragons - „Night Visions” & 53,99 & 40,99 \\
\hline Pink Floyd — „The Division Bell” & 39,99 & 43,99 \\
\hline Otsochodzi — „Nowy Kolor” & 24,99 & 35,99 \\
\hline Krzysztof Zalewski — „Złoto” & 24,99 & 36,99 \\
\hline & & 602,85 \\
\hline Suma cen & 35,39 & 40,19 \\
\hline Średnia cena zapisu cyfrowego/płyty & & \\
\hline
\end{tabular}

Źródło: opracowanie własne na podstawie danych dostępnych na stronie Empik.pl (dostęp: 21.01.2019).

Dane zebrane w tabeli 3 jasno pokazują, że ceny wersji zdigitalizowanych są niższe od wydań na nośnikach CD. Spowodowane to jest przede wszystkim tym, iż na wydanie cyfrowe nie przeznacza się takich nakładów pieniężnych, jak na wydania na płytach $\mathrm{CD}$, ponieważ odpadają koszty druku okładek, wypalania płyt oraz samych pudełek. Zdarzają się również wyjątki - na przykład cyfrowy album „Małomiasteczkowy” autorstwa Dawida Podsiadły jest droższy o 9 zł od swojego fizycznego odpowiednika.

Kasety magnetofonowe to głównie rynek wtórny — wielkie wytwórnie muzyczne nie wytwarzają tych nośników, ponieważ jest to niszowy rodzaj fonogramu, przez wielu uznawany za pamiątkę z lat 80 . i 90. Jednak wiele wskazuje, iż sytuacja może się zmienić, ponieważ w 2018 roku sprzedaż kaset wzrosła prawie 
dwukrotnie w porównaniu do roku $2017^{27}$. Małe wytwórnie decydują się na produkowanie niewielkich nakładów albumów na kasetach ze względu na pewien „prestiż” (limitowane nakłady, które mają szansę stać się kiedyś białym krukiem wśród wydań) i dosyć niskie koszty wykonania. Ceny wydań niszowych wahają się od 30 do $60 \mathrm{zł} \mathrm{w}$ zależności od rozpoznawalności danego artysty ${ }^{28}$.

Warto wspomnieć o abonamentach, które można wykupić w rozliczeniu miesięcznym na serwisach oferujących strumieniowanie muzyki. Tabela 4 prezentuje zestawienie cen i dodatkowych informacji o dostępnych dla Polaków portalach strumieniujących muzykę.

Tabela 4. Oferta portali strumieniujących muzykę w Polsce

\begin{tabular}{|l|c|c|c|c|}
\hline \multicolumn{1}{|c|}{ Usługa } & Abonament miesięczny & $\begin{array}{c}\text { Kolekcja } \\
\text { utworów } \\
\text { (w mln })\end{array}$ & $\begin{array}{c}\text { Tryb } \\
\text { offline }\end{array}$ & $\begin{array}{c}\text { Darmowy } \\
\text { odsłuch }\end{array}$ \\
\hline $\begin{array}{l}\text { Amazon } \\
\text { Music } \\
\text { Unlimited }\end{array}$ & 17 zł/rodzinny 25 zł & 40 & Tak & Nie \\
\hline Apple Music & 19,99 zł / HiFi 39,99 zł / rodzinny 29,99 zł & 30 & Tak & Nie \\
\hline Deezer & 19,99 zł / rodzinny 29,99 zł & 40 & Tak & Tak \\
\hline $\begin{array}{l}\text { Google Play } \\
\text { Music }\end{array}$ & 19,99 zł / rodzinny 29,99 zł & 35 & Tak & - \\
\hline Spotify & 19,99 zł / rodzinny 29,99 zł & 30 & Tak & Tak \\
\hline Tidal & 19,99 zł / HiFi 39,99 zł / rodzinny 29,99 zł & 25 & Tak & Nie \\
\hline
\end{tabular}

Źródło: opracowano na podstawie: https://antyweb.pl/uslugi-streamingowe-porownanie/ (dostęp: 15.12.2018).

Najpopularniejsze portale streamingowe, takie jak Spotify ${ }^{29}$, Apple Music ${ }^{30}$, Deezer $^{31}$ czy Google Play Music ${ }^{32}$, oferują nielimitowany odsłuch całej dostępnej fonoteki za 19,99 zł miesięcznie w pakiecie indywidualnym. Większość serwisów oferuje również pakiety pięcio- lub sześcioosobowe, których ceny wynoszą

27 H. Williams, Cassette sales have nearly doubled this year, but are they making a comeback?, 2018, https://mixmag.net/feature/cassette-sales-have-nearly-doubled-this-year-but-are-they-makinga-comeback (dostęp: 15.12.2018).

28 Oszacowano na podstawie wydań takich zespołów muzycznych, jak Himalaya Collective, Undadasea, DirtyBeauty, MonkedRecords - ceny zostały pobrane z profili dostępnych na stronie internetowej https://www.bandcamp.com (dostęp: 15.12.2018).

29 Szczegóły dotyczące subskrypcji: https://www.spotify.com/pl/premium/(dostęp: 18.12.2018).

30 Szczegóły dotyczące subskrypcji: https://support.apple.com/pl-pl/HT204930 (dostęp: 18.12.2018).

31 Szczegóły dotyczące subskrypcji: https://www.deezer.com/pl/offers (dostęp: 18.12.2018).

32 Ł. Kotkowski, Google przypomniat sobie o Polsce. W Google Play Music w końcu wykupisz abonament rodzinny, 2017, https://www.spidersweb.pl/2017/09/google-play-music-abonament-rodzinny.html (dostęp: 18.12.2018). 
niewiele więcej, bo 29,99 $\mathrm{zl}^{33}$. Jedynie Amazon Music Unlimited ma w swojej ofercie pakiety nieco tańsze od swoich konkurentów — indywidualny w cenie 17 zł miesięcznie, a rodzinny za 25 zł miesięcznie ${ }^{34}$.

\section{Komunikacja marketingowa na rynku muzycznym}

Zgodnie z tradycyjną koncepcją marketingu mix, zwaną również „4P” — product, price, place, promotion (produkt, cena, dystrybucja, promocja) — jesteśmy w stanie określić właściwą ścieżkę wprowadzania na rynek produktu, jakim jest tradycyjny fonogram ${ }^{35}$. Produkcja jest ściśle związana $z$ materialnymi i niematerialnymi atrybutami nośnika, a więc nazwą marki (wytwórni), oznaczeniem artysty, opakowaniem itd. Drugim etapem będzie kolejno ustalanie odpowiedniej ceny dla fonogramu, bazując na warunkach, które stawia rynek fonograficzny. Po trzecie należy zapewnić właściwą dystrybucję dobra, jakim jest nośnik dźwię$\mathrm{ku}$ - najlepiej będzie zobrazować to na podstawie schematu zaproponowanego przez P. Gałuszkę:

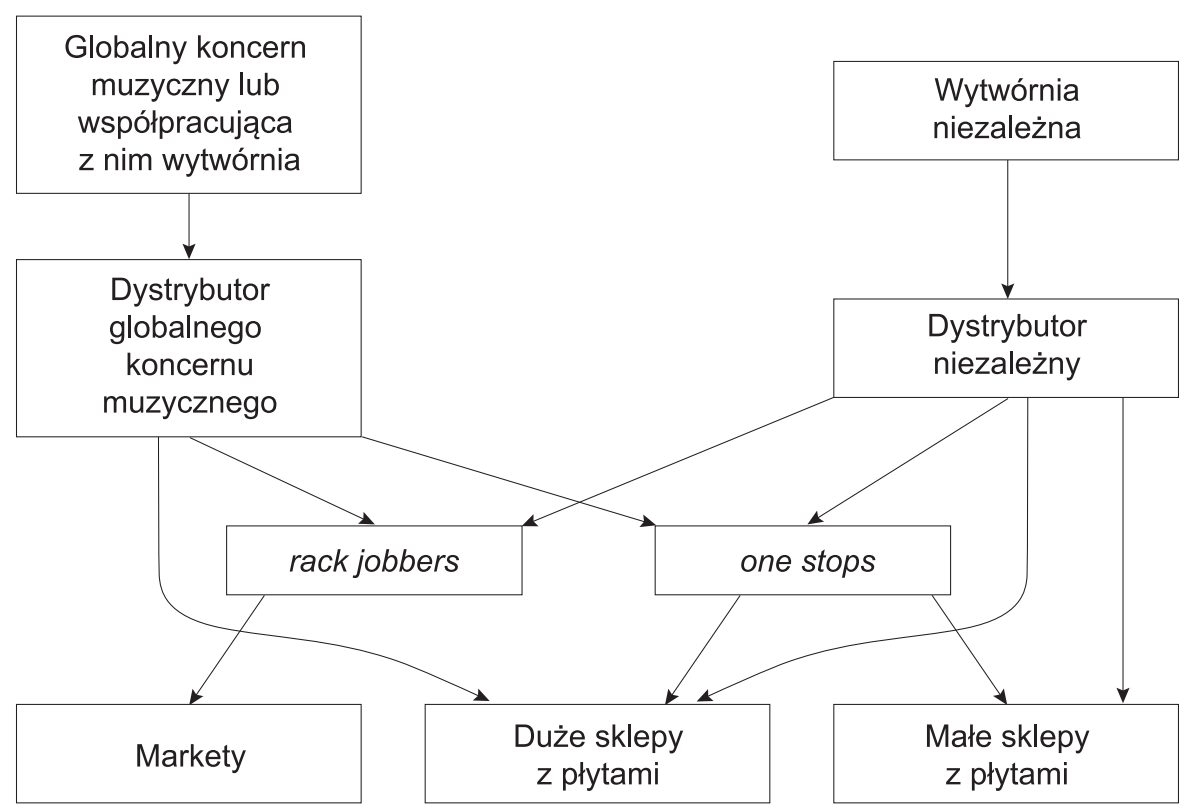

Rysunek 1. Zależność między kanałami dystrybucji nośników dźwięku

Źródło: opracowanie własne na podstawie P. Gałuszka, Biznes muzyczny..., s. 112.

33 P. Winiarski, Spotify, Tidal, Deezer, a może Apple Music — którq̨ ustugę streamingu muzyki wybrać?, 2018, https://antyweb.pl/uslugi-streamingowe-porownanie/ (dostęp: 18.12.2018).

34 Ibidem.

35 R. Strasser, Music Business - The Key Concepts, Nowy York 2010, s. 88. 
Widoczne na rysunku one stops oraz rack jobbers to podmioty skupujące płyty od dużych dystrybutorów, aby następnie sprzedawać je do mniejszych lub większych sklepów z muzyką — pośredniczą w procesie dystrybucji ${ }^{36}$.

Czwartym etapem jest promocja, czyli komunikacja między producentami i konsumentami celem zaoferowania produktów i zaznaczenia obecności na rynku.

Według P. Gałuszki komunikacja marketingowa może przybierać trzy różne formy: mass media, dystrybutorzy i detaliści oraz konsumenci ${ }^{37}$. Najczęściej przyjmowaną strategią promocyjną jest natomiast tzw. buzz creation, czyli „,kreowanie szumu" - sytuacja, w której artysta zyskuje szybko rozgłos, na jego temat pisze się w mediach masowych i w kręgach krytyków muzycznych ${ }^{38}$ (pojęcie związane z marketingiem szeptanym). W drugiej dekadzie XXI wieku jest to zdecydowanie bardziej ułatwione dzięki serwisom społecznościowym, które cechują się ogromnymi możliwościami w zakresie przepływu informacji.

Rynek fonograficzny jest ściśle związany z mass mediami — radiem, telewizją, prasą ${ }^{39}$ i Internetem - szczególnie z serwisami oferującymi możliwość odtwarzania teledysków, podcastów, relacji z koncertów itd. Szczególną formą promocji $\mathrm{w}$ radiu jest tzw. airplay, czyli odtwarzanie muzyki danego artysty na antenie, relacja z wydarzenia, na przykład koncertu, oraz sama reklama. Ta forma komunikacji opiera się na szczególnej zależności konsument-radio, która polega na tym, że potencjalny klient zakupi jedynie utwory, które już wcześniej usłyszał ${ }^{40}$. Producenci fonogramów, artyści i stacje radiowe żyją z sobą w swoistej symbiozie — każdemu z tych podmiotów zależy na odpowiedniej liczbie rozgłaszanych utworów. Odbiorcy, osłuchując się z materiałem audio, stają się bardziej skłonni do jego nabycia, a radiostacje $\mathrm{z}$ chęcią będą odtwarzać na antenie popularne utwory, które przyciągną więcej słuchaczy.

Kolejnym sposobem promocji w mass mediach jest transmisja audiowizualna, która odbywa się za pomocą telewizji oraz kanałów w internetowych, takich jak YouTube. Elementami takiej promocji są teledyski, transmisje z koncertów, wywiady oraz każda inna forma audiowizualna — na przykład soundtracki filmo$\mathrm{we}^{41}$. Taka forma promocji może natomiast okazać się bardzo kosztowna, a niektóre wytwórnie nie decydują się na wysokobudżetowe produkcje ze względu na szacowaną niską rentowność takiej inwestycji. Czasami jednak wyprodukowanie teledysku może przynieść ogromne zainteresowanie słuchaczy, które powoduje,

\footnotetext{
36 P. Gałuszka, Biznes muzyczny..., s. 115-118.

37 Ibidem, s. 129.

38 Ibidem.

39 Ibidem.

40 R. Strasser, op. cit., s. 6.

41 P. Gałuszka, Biznes muzyczny..., s. 141-142.
} 
że teledysk czy inna forma audiowizualna szybko staje się viralem ${ }^{42}$, czyli wirusowo udostępnianym przez słuchaczy materiałem wideo ${ }^{43}$.

Prasa to doskonały dodatek do dzisiejszych form komunikacji z klientem w mass mediach w branży muzycznej. Możemy wyróżnić wiele rodzajów publikacji, w których mógłby reklamować się artysta, przede wszystkim te dotyczące branży muzycznej: specjalistyczne, dotyczące popkultury, pasjonatów danego gatunku muzycznego itd., lecz również prasa codzienna i lifestylowe tygodniki czy miesięczniki ${ }^{44}$. Krótka charakterystyka albumu lub wywiad z twórcą może bezpośrednio przyciągnąc chętnych do zakupu fonogramów.

Uzupełniającymi formami promocji w branży marketingowej według P. Gałuszki są:

- Reklama - reklamowanie produktu, jakim jest album w postaci fizycznej w różnych mediach, nie przynosi dużych efektów, odbiorcy lubią się „osłuchać” z materiałem zanim zdecydują się na jego zakup. Odpowiednio dopasowana reklama wideo, na przykład w Facebook Ads, może natomiast przynieść pozytywne rezultaty przy dobrze dobranej grupie docelowej ${ }^{45}$.

— Promocje sprzedaży na szczeblu dystrybucyjnym oraz samych klientów promocja może dotyczyć naszych partnerów: oferujemy sprzedaż towaru w niższej cenie, natomiast wymagamy dobrej organizacji merchendisingowej od sprzedawcy. Dla klientów w tej formie promocji przewidziane są kupny rabatowe na dane albumy, konkursy itd ${ }^{46}$.

- Sponsoring - tak jak w przypadku radia, są to działania o charakterze symbiotycznym: firma sponsorująca artystę może zyskać na jego popularności, a muzyk zyskać nowych fanów - klientów tego przedsiębiorstwa ${ }^{47}$.

- Cross promocje - oferowanie produktu, jakim jest nośnik dźwiękowy wraz z innym produktem, który pochodzi od niekonkurencyjnej marki. Najlepsza sytuacja jest wtedy, gdy produkty się uzupełniają — na przykład płyta CD i odtwarzacz typu Walkman. W tej strategii bardzo często stosowane są obniżki cen w przypadku zdecydowania się na obydwa dobra na raz ${ }^{48}$. W tym przypadku doskonałym przykładem jest również pojawianie się artystów na pokazach produktowych, filmach znanych youtuberów czy streamingach $\mathrm{z}$ gier. Taki ruch wykonał na przykład raper Drake, grając w Fortnite wraz ze znanym streamerem Ninja podczas jednego z pokazów na żywo na platformie Twitch. Nietrudno się

42 Inbmarketing, Tajemnice marketingu wirusowego (viral marketing), https://inbmarketing. pl/tajemnice-marketingu-wirusowego-viral-marketing/ (dostęp: 5.01.2019).

43 J. Kirby, P. Marsden, Connected Marketing, Oxford 2006, s. 87-88.

44 P. Gałuszka, Biznes muzyczny..., s. 148-149.

45 Ibidem, s. 151.

46 Ibidem, s. 152.

47 Ibidem, s. 153-154.

48 J. Hardy, Cross-Media Promotion, Nowy York 2010. 
domyślać, jakie korzyści dla obydwu panów przyniosła taka strategia — został wówczas pobity rekord oglądalności na tym serwisie, momentami liczba widzów przekraczała 600 tysięcy osób ${ }^{49}$.

- Media tour - synchronizacja wydania fonogramu wraz ze wszystkimi ważnymi występami artysty w mass mediach ${ }^{50}$.

- Listening session - przedpremierowy pokaz muzyczny dla zamkniętego grona słuchaczy (na przykład krytyków muzycznych) — taka strategia pozwala zbudować dobrą markę nadchodzącemu albumowi zanim pojawi się na półkach sklepowych ${ }^{51}$.

Oprócz propozycji P. Gałuszki uzupełniających standardowy model komunikacji marketingowej można wyróżnić jeszcze:

- Content marketing i social media marketing — marketing treści to w dzisiejszych czasach potężne narzędzie pozwalające w bezpośredni sposób wchodzić $\mathrm{w}$ interakcje $\mathrm{z}$ fanami ${ }^{52}$. Właściwe budowanie tekstów, grafik i infografik na fanpage'ach $w$ mediach społecznościowych może w znacznym stopniu pomóc w zdobyciu uznania wśród internautów, a także ułatwić dostęp do samej twórczości artysty ${ }^{53}$.

- Charity marketing — działalność charytatywna prowadzona przez artystę — buduje dobry wizerunek wśród fanów ${ }^{54}$.

Trudno charakteryzować komunikację marketingową, która dotyczy cyfrowych nośników dźwięku oraz streamingów muzyki. Brakuje tutaj bowiem klasycznej sfery dystrybucyjnej, wszystko odbywa się w sieci. Wytwórnia nawiązuje kontrakty z serwisami strumieniującymi muzykę na dane utwory, udostępnia je $\mathrm{w}$ formie elektronicznej, a te dalej wprowadzane są na rynek jako zdigitalizowane albumy muzyczne. Wszystko odbywa się na zasadzie uploadu i downloadu, a dystrybucja ogranicza się jedynie do relacji wytwórnia-streaming/portal z cyfrową muzyką-klient. Jeśli chodzi o promocję $\mathrm{w}$ takim przypadku, to zdecydowanie najlepszym rozwiązaniem dla artysty będzie skupienie się na mediach społecznościowych i dobrym content marketingu — udostępnianie treści zdigitalizowanych

49 K. Kacperski, Ninja i Drake pobili rekord oglądalności Twitcha swoim streamem z „Fortnite”, 2018, https://www.antyradio.pl/Technologia/Gry/Ninja-i-Drake-pobili-rekord-ogladalnosci-Twitcha-stwoim-streamem-z-Fortnite-21154 (dostęp: 5.01.2019).

50 P. Gałuszka, Biznes muzyczny..., s. 154.

51 Ibidem, s. 154-155.

52 M. Szczurski, Muzyka popularna - sztuka, czy produkt? Marketing treści i strategia promocji na rynku muzycznym, 2016, https://marketingibiznes.pl/content-marketing/strategia-promocji-na-rynku-muzycznym/ (dostęp: 5.01.2019).

53 T. Brusik, CASE: Jak promować muzykę w Social Media?, 2017, https://semahead.pl/blog/ case-promowac-muzyke-social-media.html (dostęp: 5.01.2019).

${ }^{54}$ N. Mali, Charity Marketing - the Ultimate Guide, 2018, https://appinstitute.com/charity-marketing/ (dostęp: 5.01.2019). 
przez swój fanpage może pomóc dotrzeć do klientów, którzy nie kupują już tradycyjnych nośników dźwięku. Zawiązanie współpracy na przykład ze Spotify, by udostępnić swój wizerunek w celach reklamowych, również mogłoby się wiązać ze sporymi profitami w postaci promocji i samego zysku dla artysty.

\section{Podsumowanie}

W dobie szeroko rozumianego rozwoju technologicznego jesteśmy świadkami zmiany dystrybucji dobra, jakim jest fonogram. Odchodzi się powoli od tradycyjnych nośników dźwięku i zastępuje się je wygodną formą — strumieniowaniem oraz cyfrową muzyką, którą możemy zabrać z sobą w praktycznie każde miejsce na Ziemi. Równocześnie na popularności zyskują bardziej niszowe nośniki dźwię$\mathrm{ku}$ - płyty winylowe oraz kasety magnetofonowe. Trudno jednak określić, czy trend na te fonogramy będzie utrzymywał się na wysokim poziomie, czy wkrótce muzyka w pełni zdigitalizowana wyprze ten rodzaj nośników i będzie najpopularniejszą formą odsłuchu audio.

Wyniki ankiety dowiodły, iż preferencje zakupowe Polaków nie odstają w dużym stopniu od tych zgłaszanych przez zachodnich nabywców fonogramów. W ciągu roku ankietowani wydają ponad 350 zł na nośniki dźwięków, kupując ich około 7-8 w ciągu roku. Osoby badane wskazały, że najczęściej wybieranym przez nie fonogramem jest płyta $C D$, jednak globalna tendencja do udostępniania muzyki strumieniowanej może niedługo zmienić preferencje Polaków co do samego nośnika. Ankietowani zaznaczyli również, że jakość nagrania ma najważniejszy wpływ na to, czy zakupią dany nośnik dźwięku, czy też nie.

Zmiany, które bardzo szybko następują na rynku fonograficznym, wymuszają na artystach poszukiwanie nowych form promocji, które najczęściej budują skuteczny content marketing w połączeniu z sukcesywnym tworzeniem własnego wizerunku w mediach społecznościowych. $Z$ takiego rozwoju wydarzeń korzystają na pewno mniej znani muzycy, którzy bez problemu mogą, za niewielką opłatą, udostępnić swoje utwory w witrynach streamingowych i w ten sposób dotrzeć do ogromnej liczby słuchaczy. Oprócz serwisów strumieniujących muzykę istnieją również platformy, które służą jako miejsce darmowego odsłuchu i finansowego wsparcia twórczości niszowych artystów. Są to między innymi takie portale, jak bandcamp.com czy soundcloud.com, które w znacznym stopniu pozwalają zwiększyć odtworzenia organiczne utworów, a nawet całych albumów.

\section{Bibliografia}

Apple, Szczegóty dotyczące subskrypcji, https://support.apple.com/pl-pl/HT204930.

Bandcamp, O nas, https://bandcamp.com/about.

Brusik T., CASE: Jak promować muzykę w Social Media?, 2017, https://semahead.pl/blog/case-promowac-muzyke-social-media.html. 
Business Wire, The Nielsen Company \& Billboard's 2012 Music Industry Report, 2013, https://www. businesswire.com/news/home/20130104005149/en/Nielsen-Company-Billboard\%E2\%80\% 99s-2012-Music-Industry-Report\#.VF6Ts5_YiDw.

Christman E., Nielsen 360 Study Finds Consumers Love Streaming Music, But Radio Still Strong, 2017, https://www.billboard.com/articles/business/8031468/nielsen-music-360-2017-report-streaming.

Deezer, szczegóły dotyczące subskrypcji: https://www.deezer.com/p1/offers.

Gaille B., 25 Good Hip-Hop Demographic, 2015, https://brandongaille.com/25-good-hip-hop-demographics/.

Gajewski M., Amerykanie już nie chca muzyki na własność. Wystarcza im ta strumieniowana, 2018, https://www.spidersweb.pl/rozrywka/2018/07/12/muzyka-strumieniowanie-kontra-kupowanie/.

Gałuszka P., Biznes muzyczny - ekonomiczne i marketingowe aspekty fonografi, Placet, Warszawa 2009.

Gałuszka P., Największe koncerny muzyczne - majors, 2007, http://pga.blox.pl/2007/06/Najwieksze-koncerny-muzyczne-majors.html.

Gałuszka P., Kartajaya H., Setiawan I., Marketing 4.0, MT Biznes, Warszawa 2017.

Gałuszka P., Korzeniewska K., Wyrzykowska K.M., Jagiełło-Skupińska A., Rynek fonograficzny w Polsce 2011/2012, Instytut Muzyki i Tańca, Warszawa 2013.

Hardy J., Cross-Media Promotion, Peter Lang, Nowy York 2010.

Harris M., 6 Best Online Music Sites for Downloading Songs, 2019, https://www.lifewire.com/bestonline-music-sites-for-downloading-songs-2438415.

Inbmarketing, Tajemnice marketingu wirusowego (viral marketing), https://inbmarketing.pl/tajemnice-marketingu-wirusowego-viral-marketing/.

Ingham T., Independents ruled global market share in 2017 — but Universal was king of streaming, https://www.musicbusinessworldwide.com/independents-ruled-global-market-share-in-2017but-universal-was-king-of-streaming/.

Kacperski K., Ninja i Drake pobili rekord oglądalności Twitcha stwoim streamem z „Fortnite”, 2018, https://www.antyradio.pl/Technologia/Gry/Ninja-i-Drake-pobili-rekord-ogladalnosci-Twitcha-stwoim-streamem-z-Fortnite-21154.

Kirby J., Marsden P., Connected Marketing, Elsevier, Oxford 2006.

Kotkowski Ł., Google przypomniat sobie o Polsce. W Google Play Music w końcu wykupisz abonament rodzinny, 2017, https://www.spidersweb.pl/2017/09/google-play-music-abonament-rodzinny.html.

Kotler P., Armstrong G., Saunders J., Wong V., Marketing: podręcznik europejski, Polskie Wydawnictwo Ekonomiczne, Warszawa 2002.

Legalna Kultura, Jak dystrybucja cyfrowa zmienia muzykę — debata w Opolu, https://www.legalnakultura.pl/pl/legalna-kultura/dzialamy/blog/1175,jak-dystrybucja-cyfrowa-zmienia-muzyke-debata-w-opolu.

Mali N., Charity Marketing - the Ultimate Guide, 2018, https://appinstitute.com/charity-marketing/.

Pop Run The World, Jak dzieli się rynek muzyczny?, 2014, https://popruntheworld.wordpress.com/ 2014/10/07/jak-dzieli-sie-rynek-muzyczny/.

Raport IDiA, Research Music Subscriber Market Share Model 09/18, https://musicindustryblog.wordpress.com/2018/09/13/mid-year-2018-streaming-market-shares/.

Raport IFPI, Global Music Raport - Annual State of Industry, 2018.

Rosenblatt B., Vinyl Is Bigger Than We Thought. Much Bigger, 2018, https:/www.forbes.com/sites/ billrosenblatt/2018/09/18/vinyl-is-bigger-than-we-thought-much-bigger/\#55cfa75a1c9c.

Szczurski M., Muzyka popularna - sztuka czy produkt? Marketing treści i strategia promocji na rynku muzycznym, 2016, https://marketingibiznes.pl/content-marketing/strategia-promocji-na-rynku-muzycznym/.

Spotfiy, O nas, https://support.spotify.com/us/.

Studenckie Prace Prawnicze, Administratywistyczne i Ekonomiczne 27, 2019

(C) for this edition by CNS 
Spotify, szczegóły dotyczące subskrypcji: https://www.spotify.com/pl/premium/.

Statista, Most popular music streaming services in the United States as of March 2018, by monthly users (in millions), 2018, https://www.statista.com/statistics/798125/most-popular-us-music-streaming-services-ranked-by-audience/.

Strasser R., Music Business — The Key Concepts, Routlege, Nowy York 2010.

Williams H., Cassette sales have nearly doubled this year, but are they making a comeback?, 2018, https://mixmag.net/feature/cassette-sales-have-nearly-doubled-this-year-but-are-they-makinga-comeback.

Winiarski P., Spotify, Tidal, Deezer, a może Apple Music — która usługę streamingu muzyki wybrać?, 2018, https://antyweb.pl/uslugi-streamingowe-porownanie/.

\section{Trends of changes on the music market in Poland}

\section{Summary}

In the era of broadly understood technological development, we are witnessing a change in the distribution of phonograms. It moves slowly away from traditional phonograms such as CDs, Vinyl and Cassettes and is replaced by a convenient form - streaming and digital music that we can take with us to any place on earth. At the same time, more niche sound carriers - vinyl records and audio cassettes - are gaining popularity. However, it is difficult to determine whether the trend for these phonograms will be maintained at a high level, or soon the fully digitized music will replace this type of media and will be the most popular form of audio listening.

The results of the survey showed that the shopping preferences of Poles do not stand out greatly from those reported by the western buyers of phonograms. During the year, the respondents spend over PLN 350 on sound carriers, buying them around 7-8 pieces a year. The respondents indicated that the most frequently chosen phonogram is a $\mathrm{CD}$, but the global trend towards streaming music may soon change the Poles' preferences. The respondents also pointed out that the quality of the recording has the most important impact on whether they buy a phonogram or not.

The changes, which very quickly take place on the phonographic market, force artists to look for new forms of promotion, which are often based on effective content marketing combined with the successive building their image in social media. Such solutions are used by lesser-known musicians, who can easily make their songs available on streaming sites and reach a large number of listeners for a small fee. In addition to websites that stream music, there are also platforms that serve as a place for free listening and financial support for the creativity of niche artists. These are, among others, such portals as bandcamp.com or soundcloud.com, which to a large extent allow to increase the organic number of listens songs and even entire albums. 